\title{
STRATEGIC MEASURES FOR IMPROVING THE QUALITY OF PUBLIC TRANSPORT SERVICES: APPROACHES TO FORMATION
}

\author{
Maksym Borozenets ${ }^{1}$
}

\begin{abstract}
The subject of the study is the formulation of strategic measures to improve the quality of public transport services. The goal is to justify a set of strategic measures aimed at improving the quality of public transport services. To achieve this goal, the following research objectives have been identified and solved: to establish the specifics and principles of effective strategic planning for urban transport services provision; to identify the features of urban transport services system; to identify the main measures for urban public transport services development, in particular, for the city of Kyiv. To achieve the goal of the study, a set of system theory methodologies has been selected. In modern science, this approach is considered to be the most productive and capable of providing a high degree of verification of the results obtained. As a result of the study: 1) a complex of strategic measures is substantiated, aimed at improving the quality of public transport services, namely: optimization of modal transportation; integration of modal transportation; optimization of road space; increasing the bus fleet; improving bus design and increasing the comfort in passenger compartments; selection of fare forms; development of information systems of interaction; compliance with the Traffic Laws and passenger transportation rules; increase of internal efficiency of transport operators' activities; use of information technologies; increase of transport operators' incomes; 2 ) the specifics and principles of effective strategic planning for urban transport services provision are established. They consist in applying an iterative approach to strategic planning. Its advantages are due to simultaneous execution of any strategic planning work (from writing the following elements of the strategic plan to the fulfilment of its objectives) with continuous analysis of results obtained, which makes it possible to adjust the works according to the changing environment conditions; 3 ) the features of the urban transport service systems are revealed, namely: urban public transport systems are complex open dynamic socio-economic systems. We consider multimodality of external environments, multifactoriality of external influences, presence of internal imbalances in systems as one of the main reasons for their unsatisfactory state. Therefore, a multifaceted approach is needed, which takes into account the maximum number of factors and combines a range of measures to improve the quality of urban passenger transportation; 4) the main measures for the development of urban public transport services, in particular, for the city of Kyiv, are identified, namely: ensuring multimodal public access to public transport stations and public places; organization of information and communication interaction between all elements of the passenger transportation system; use of various forms of urban public transport fare; mathematical modelling of integration interaction of different types of public transport.
\end{abstract}

Key words: public transport, quality of service, strategic activities, public administration, urban management.

JEL Classification: M38, R49, R58, L9, L38

\section{Introduction}

The relevance of research is determined by a set of objective factors. One of the problems of modern towns in Ukraine is the insufficient quality of transport services provided. We have identified the implementation of a holistic "Total quality management" approach (TQM) as a main vector for improving the transport services provision. It plays a major role in TQM implementation. It is about both organizational management and management of higher-level systems, in particular, the system of services provided within the territorial community. It allows you to identify and implement priorities, systematize all factors of

\footnotetext{
Corresponding author:

${ }^{1}$ National Academy for Public Administration under the President of Ukraine, Ukraine

E-mail: V_Koltun@yahoo.com

ORCID: https://orcid.org/0000-0003-3417-8213
} 
quality formation, motivate its provision, organize step-by-step effective control. Strategic quality management is of particular importance.

The problem of quality of passenger transportation services is explored by modern scientists, both domestic and foreign. We should point out the fundamental achievements of the Ukrainian scientists: Adler Yu.P., Ihnatenko D.O., Ihnatenko O.S., Markova V.D., Nesterenko P.A., Polhovskaya T.M., Shper V.L., Fedyukin V.K., Yanovskyi P.O. The scientific achievements of the following foreign scientists is significant: Akao Y., Anderson E.W., Battellino, H., Bryant B.E., Buliung, R., Cha J., Fornell C., Mitra G., Johnson M.D. At the same time, as the analysis shows, the issues of improving the quality of public transport services in the strategic planning aspect have not yet been the subject of a special study, which led to the choice of the topic of this research.

The article goal is to substantiate a set of strategic measures aimed at improving the quality of public transport services. To achieve the goal, the following research objectives have been identified: to establish the specifics and principles of effective strategic planning for the urban transport services provision; to identify the features of urban transport services system; to identify the main measures for the development of urban public transport services, in particular, for the city of Kyiv.

In order to achieve the set objectives and the research goal formulated, we have chosen a set of system theory methodologies, because this approach is considered the most productive in modern science and capable of providing a high degree of verification of the results obtained.

In accordance with the goal, the presentation logic is defined, based on the principle of ascent from abstract to concrete. The analysis starts with defining the principles and approaches of effective strategic planning, establishing the typology of urban public transport systems. Based on the above elements of the study, the result was obtained, which allow formulating adequate measures of strategic planning of quality assurance of urban public transport services.

\section{Strategic planning for the development of urban public transport services}

An insufficiently high level of satisfaction of passengers of the urban public transport (first of all of bus routes) requires strategic planning of its development. Strategic planning and development of program of urban public transport services development on the basis of improving the quality of passenger service includes several stages of successive transformation (reforming) of the existing transport system of the urban territorial community (Taguti, Fadke, 2013; Fomin, 2010). Separate stages of strategic plan development can be used iteratively. Thus, if the prospective goals of public transport services development cannot be fully achieved, at least in the medium term, the parameters of such limiting factors as available financial resources, current organizational and regulatory frameworks or technical capabilities of transport operators should be revised. In these cases, the earlier stages of the strategic plan can be revised and updated in the light of the expected results or problems that arise in the process of accomplishing the previous tasks. It may sometimes be appropriate to even change the stated goals of public transport services development or to add some incentive measures to an already developed strategic plan. In the long run, it is sometimes possible and appropriate to change the previously considered external conditions for the operation of urban public transport.

We proceed from the fact that there are the following major advantages of an iterative approach to strategic planning: all aspects of the developed strategic plan for the public transport services development are subject to critical analysis; consideration is given both to the overall coherence of the strategic plan as well as the coherence of its individual steps and elements; even an acceptable version of the strategic plan can be improved and optimized; potential strategic plan weaknesses can be identified and corrected already at the planning stage, rather than at the implementation stage, which is an obvious problem of reviewing programs and activities; the contradictions between the actors of the urban public transport system can be mitigated on the basis of a more active involvement of all stakeholders, including consumer NGOs as the most important participants in the strategic plan development process.

\section{Urban transport services system}

Urban public transport is a complex transport system. In order to create an efficient and quality service, it is necessary to find out the relationship between its separate components. Complexity exists both within service provider organizations (transport operators) as well as the environment 
of service provision. As a macroeconomic external environment affecting the transport system, the following set of socio-economic features is considered: socio-economic profile of the community, demographic profile, forecasts, regulatory framework, institutional framework, prospect of town development. In turn, the microeconomic external environment for urban public transport services, including bus services, should be assessed on the following criteria: capacity and accessibility of urban bus transportation infrastructure; competing modes of transport, including motorless vehicles; capacity of the bus fleet and a description of the services providing, their strengths and weaknesses; description of other public transport service providers, their strengths and weaknesses, modes of use; assessment of public transport services consumer satisfaction, market segmentation; assessment of existing scenarios for the public transport development, in particular bus transportation; assessment and diagnosis of major problems. A strategic analysis of the current situation of urban public transport service provision is a major step in the service development process. The objectives of this phase are to identify factors affecting the bus transport services provision, to describe the current situation of service provision, to evaluate the transport system and to diagnose identified problems. A thorough understanding of the existing bus service transport environment greatly influences strategic aims and plans development. Much of the necessary information and useful data can be obtained as early as at the development of the Strategic Mobility Plan. The stage of setting goals for improving the quality of urban bus transportation services is an important element in the strategic planning process. To what extent this stage will be significant depends on the structure and potential of a town, as well as the assessment of the current state of service provision. As a rule, this phase is conducted with the participation of key stakeholders and reflects the diversity of their views and interests, which, however, involves reaching consensus on the goals and objectives pursued, as well as measures to achieve them. The objectives of this phase are to identify key stakeholders and consult with them, to develop a set of goals and objectives relevant to urban passenger bus transportation, to identify potential constraints and social, economic, environmental, technological and managerial factors affecting the process (Hazanova, 2008).
The purpose of the next stage is to develop strategic options for improving urban bus service, depending on the urban environment particularities. Modern towns are a heterogeneous community of different groups of urban population, types of land use, road transport infrastructure, types of public transport, forms of traffic management. So, urban road space is used by buses, cars, electric vehicles, bicycles and pedestrians, therefore generating strategies for developing and improving quality of services is a difficult task. Strategic decisions will vary depending on these urban conditions and will be determined by the prevailing factors and formulated goals.

Urban public transport systems are complex socio-economic systems. Multifactorial external influences, internal imbalances in systems are considered one of the main reasons for their unsatisfactory condition. Adopting a single, albeit scientifically sound, decision to improve the quality of bus services will not have the desired effect, since its benefits will not extend to the entire transport system. Therefore, a multifaceted approach is needed, combining a set of measures to improve the quality of urban bus transportation.

\section{Development of urban public transport services}

The main measures for the development of urban public transport services include: 1. Optimizing and integrating of transportation by different types of urban public transport. 2. Optimizing the use of road space to ensure priority for public transport. 3. Choosing options for increasing the bus fleet capacity, improving the bus design, streamlining the fare system. 4. Increasing accessibility of town buses to socially vulnerable citizens and people with disabilities. 5. Ensuring proper enforcement of passenger rules and improving the internal efficiency of the modal system. 6. Use of information and communication technologies, including means of communication with the driver and feedback from the transport operator. 7. Application of modern economic-mathematical methods and models of management decision-making by transport operators and local self-government bodies.

Optimizing and integrating transportation by different types of urban public transport is about choosing the best options for using public transport and modes of transportation. Each mode of population displacement has its advantages and disadvantages. This also applies to pedestrians, 
cyclists and riding an individual electric vehicle, which should be taken into account in optimal planning. As a result, road space and passenger traffic should be divided among different users, including personal transport, pedestrians and cyclists. Bus transportation is used for trips longer than $4-5 \mathrm{~km}$. In addition, almost every bus trip is associated with one or more passenger transfers and therefore a pedestrian traffic. Therefore, the importance of motorless modes must be taken into account and provided with infrastructure. In this case, the motorless modes will not compete for the road space with the buses, but will complement the bus service. Optimizing the use of different modes of transport involves managing demand for transportation services. Demand management can take many forms, such as some restrictions on the use of personal vehicles (paid and intercepted parking, restrictions on the use of official vehicles, organized transportation of pupils and students during rush hours, differentiated rates of taxation on vehicles, toll zones). Some of these measures will require legislative support, but many may be implemented by the local government within their authority. Integration of all modes of passengers' transportation (movement) is carried out by the centralized management of the process of use of all modes of transport and general road-transport infrastructure. At present, there is no proper integration of service provision by all modes of transport and within each of them. As a result, there are, for example, overlapping bus, tram and trolley bus routes, and demand for transportation services in some large and remote urban areas is not being met. Each mode of transportation must be aimed at fully meeting the demand of the population within the integrated public transport system. The lack of centralized management of all transport modes is the main reason for the low degree of integration. One form of complex planning of urban public transport use may be organizing a transportation management committee with the participation of all stakeholders' representatives, including non-governmental organizations operating in the respective territorial community.

There are opportunities to integrate bus services with other modes of transport. For example, the Central Bus Station and the Railway Station have the ability to make a smooth and easy transition from one transportation mode to another, which can be used in planning and optimizing transportation services. Optimizing the use of road space to ensure priority for public transport. According to experts, buses as a means of public transport less pollute the environment and require less roadway and fuel than a car per 1 passenger-kilometre. Despite this, there is considerable competition of buses and other public and private transport for roadway and bus stops. One of the measures aimed at increasing the use of buses as a means of urban public transport is to ensure their priority over private cars by restricting car access to certain places, prohibiting parking on some roads and near stops, and giving priority to buses over other types of public transport on already dedicated special lanes. The choice of options for increasing the capacity of the bus fleet, improving bus design, streamlining the fare system are important factors for developing bus transport services and improving their quality. Much of public transport is communal property, but a significant amount of services is provided by private transport operators (minibuses and microbuses), which do not properly plan their transportation service activities and do not coordinate it with other modes of public transport. Such operations are carried out on a purely commercial basis and cannot be regarded as the provision of organized public transport services.

There is a widespread belief that the city of Kyiv does not have enough buses to meet the demand for passenger transportation. However, this position is not scientifically justified, as there are always reserves to improve the quality of urban bus services. Thus, the conducted researches of existing reserves of improvement of quality of services are estimated in the amount of $25.8 \%$. Increasing the number of buses and the quality of service can take several forms, and the available options for improving the quality of service depend on the service scenarios developed. The existing town bus fleet is characterized by bus standard types. These buses are usually not quite modern with wide pneumatic doors, low floor and rear engine layout etc. High bus floor and narrow doors make boarding and landing difficult for many categories of people and take a long time. In addition, high floor and narrow doors often lead to accidents and are a major problem for disabled passengers, the elderly and children. Currently, there are 546 lowfloor buses in the utility company. They have all the desirable characteristics of city buses; however, they are more expensive. Transport operators have a wide choice of bus transport, from mini-buses to modern low-floor and even articulated buses. The 
high starting cost of modern buses is offset in the long run by the benefits of improved ride, higher safety standards, optimized commercial speed and ease of access for all categories of population.

Passenger fare and revenue management are considered to be the backbone of transport operators' business for several reasons: fares are the main source of income. If pricing is optimal, then the transport operator is able to maximize the potential revenue and therefore increase the profitability of the transportation; fares affect the demand of the population for travel, and a travel restriction is possible for vulnerable low-income groups; inefficient or poorly designed travel billing system can lead to increased costs and reduced vehicle performance; suboptimal system of fares and forms of payment create possibilities of evasion from payment and fraud of route crews. The structure of the fare is currently determined by the local government. However, it is recommended that all stakeholders consider alternative tariff systems. According to a city bus passengers' survey, many of them are in favour of increasing bus fares while significantly improving the quality of service. Although the main source of revenue for bus and utility companies is fare, there is some potential for revenue growth from other sources of revenue, including advertising. Organizations usually own land parcels of bus depot and parks within the city. The enclosures of these land parcels can be used for advertising purposes, in addition, some of them may be leased. Promotional messages can also be placed on buses and ticket outlets (for towns where electronic tickets have not yet been introduced), on scrolling text lines at passenger compartments. Ensuring proper implementation of the passenger rules and improving the system internal efficiency requires a high level of organization for all road users. Failure to adhere to the rules of passenger rules will, in the end, reduce the quality of public transport services. On the contrary, proper enforcement of the rules leads to more orderly behaviour on the roads, efficient use of road space and provides a level playing field for all road users. Strict adherence to the road regulations and passenger rules should be preceded by a campaign to better inform the population of their contents, as well as the provision of quality objects of road transport infrastructure. Improving the efficiency of urban bus transport, both in the public and private sectors, requires appropriate action. For example, some transport organizations may be effective in terms of higher revenue or lower costs, but have problems in terms of low staffing, outdated service practices, high levels of theft, lack of route planning and control mechanisms, low motivation, etc. If these negative factors are present in the activity of transport operators, they must be identified and measures must be taken to eliminate them. The efficiency of transport operators is closely linked to the quality of passenger service, so the developed service quality targets are an important guideline in managerial decisions. Use of information and communication technologies, including means of communication with the driver and feedback from the transport operator are necessary for monitoring the bus movement on routes, maintaining documentation, drawing up and tracking of bus maintenance schedules, solving problems of passengers during transportation, boarding and landings, etc. All of this data is easy to computerize as it can be processed and presented for decision making. Modern communications (GPS) are used to monitor bus traffic on routes and to inform passengers online. The list of individual measures considered above of strategic plan for the development of urban bus transport services and for improvement the quality of service is presented in the Table 1.

An important management decision of communal bus transportation operators is the optimal distribution of limited financial resources and budget subsidies in certain lines of activity to improve the passenger service quality and implement their measures. Since the possible number of measures to improve the quality of passenger bus service is significant, the optimal fund distribution concerns not specific measures of the strategic plan, but integrated directions for service quality improving.

\section{Conclusions}

As a result of the study:

1) the complex of strategic measures is substantiated, aimed at improving the quality of public transport services, namely: optimization of modal transportation; integration of modal transportation; optimization of road space; increasing the bus fleet; improving bus design and increasing the comfort in passenger compartments; selection of fare forms; development of information systems of interaction; compliance with the Traffic Laws and passenger transportation rules; increase of internal efficiency of transport operators' 
Vol. 1, No. 1, 2020

Table 1

Measures of strategic plan for the development of urban bus transport services and improvement of quality of service

\begin{tabular}{|c|c|c|c|}
\hline Activities & Necessary solutions & \begin{tabular}{|c|} 
Advantages \\
\end{tabular} & Effects \\
\hline $\begin{array}{l}\text { Modal transportation } \\
\text { optimization }\end{array}$ & $\begin{array}{l}\text { Defining the role of all modes of } \\
\text { transport. } \\
\text { Establishment of the territory of } \\
\text { bus service. }\end{array}$ & $\begin{array}{l}\text { Elimination of duplicates. } \\
\text { Restoration of the missing } \\
\text { elements. } \\
\text { Approximation of the modes } \\
\text { to the optimum combination. }\end{array}$ & $\begin{array}{l}\text { All modes of transportation } \\
\text { play roles according to } \\
\text { the overall mobility and } \\
\text { accessibility plan. }\end{array}$ \\
\hline $\begin{array}{l}\text { Integration of modal } \\
\text { transportation }\end{array}$ & $\begin{array}{l}\text { Rationalizing and restructuring of } \\
\text { existing transportation routes }\end{array}$ & $\begin{array}{l}\text { More efficient use of vehicles, } \\
\text { personnel and resources. }\end{array}$ & $\begin{array}{l}\text { Improving transportation } \\
\text { efficiency and quality of } \\
\text { service }\end{array}$ \\
\hline Road space optimization & $\begin{array}{l}\text { Prohibition of parking of vehicles } \\
\text { on the roads. } \\
\text { Dedicated lanes for public transport } \\
\text { (based on the experience of the city } \\
\text { of Kyiv). } \\
\text { Permission for access to densely } \\
\text { populated areas by public transport } \\
\text { only. }\end{array}$ & $\begin{array}{l}\text { Improving access to public } \\
\text { transport. } \\
\text { Optimization of commercial } \\
\text { speed. } \\
\text { Reducing the number of } \\
\text { accidents. }\end{array}$ & $\begin{array}{l}\text { Increasing population } \\
\text { mobility and accessibility. } \\
\text { Increasing the quality of } \\
\text { passenger service. }\end{array}$ \\
\hline Increase in bus fleet & $\begin{array}{l}\text { Consideration of the possibility of } \\
\text { expanding the territory of the bus } \\
\text { fleet, increasing the staff. } \\
\text { Determining the increase in the } \\
\text { quality of transportation and } \\
\text { service. }\end{array}$ & $\begin{array}{l}\text { Increasing transportation } \\
\text { frequency, accessibility and } \\
\text { mobility. } \\
\text { Reducing bus overload at } \\
\text { peak hours. }\end{array}$ & $\begin{array}{l}\text { Increase in capital } \\
\text { expenditures/ } \\
\text { Improving the quality of } \\
\text { transportation and service. }\end{array}$ \\
\hline $\begin{array}{l}\text { Improvement of bus } \\
\text { design and increase of } \\
\text { comfort in passenger } \\
\text { compartments. }\end{array}$ & $\begin{array}{l}\text { Purchase of modern buses with } \\
\text { increased accessibility and } \\
\text { ergonomic functions. }\end{array}$ & $\begin{array}{l}\text { Improving comfort. } \\
\text { Reducing the number of } \\
\text { accidents. }\end{array}$ & $\begin{array}{l}\text { Increase in capital } \\
\text { expenditures. } \\
\text { Improving comfort. } \\
\text { Increased population } \\
\text { accessibility and mobility. }\end{array}$ \\
\hline Selection of fare forms & $\begin{array}{l}\text { Consideration of alternative fare } \\
\text { forms. } \\
\text { Choosing the best fare form. }\end{array}$ & $\begin{array}{l}\text { Reducing free travel. } \\
\text { Providing benefits for social } \\
\text { groups. }\end{array}$ & $\begin{array}{l}\text { Maximize income and profit. } \\
\text { Optimization of some } \\
\text { operations and management } \\
\text { functions. }\end{array}$ \\
\hline $\begin{array}{l}\text { Development of } \\
\text { information systems of } \\
\text { interaction }\end{array}$ & $\begin{array}{l}\text { Institutionalization of public } \\
\text { consultation mechanisms. } \\
\text { Establishing effective passenger } \\
\text { complaint and suggestion handling } \\
\text { procedures }\end{array}$ & $\begin{array}{l}\text { Reinforcement of feedback } \\
\text { with the transport operator. } \\
\text { Greater public involvement in } \\
\text { problem solving. }\end{array}$ & $\begin{array}{l}\text { Improving the service quality } \\
\text { and passenger satisfaction. } \\
\text { Increased awareness of } \\
\text { transport operators. }\end{array}$ \\
\hline $\begin{array}{l}\text { Compliance with Traffic } \\
\text { Laws and passenger } \\
\text { transportation rules. }\end{array}$ & $\begin{array}{l}\text { Strengthening requirements for } \\
\text { compliance with laws and rules. } \\
\text { Monitoring the implementation of } \\
\text { the passenger transportation rules. } \\
\text { Promoting Traffic Laws. }\end{array}$ & $\begin{array}{l}\text { More efficient use of road } \\
\text { space. } \\
\text { Ensuring a level playing field } \\
\text { for all service providers. }\end{array}$ & $\begin{array}{l}\text { Reducing accidents and road } \\
\text { accidents }\end{array}$ \\
\hline $\begin{array}{l}\text { Improvement of internal } \\
\text { efficiency of transport } \\
\text { operators' activity. }\end{array}$ & $\begin{array}{l}\text { Development of repair base. } \\
\text { Investing in vehicle purchase. } \\
\text { Training of personnel. }\end{array}$ & $\begin{array}{l}\text { Improvement of activity } \\
\text { of transport organizations } \\
\text { personnel. } \\
\text { Improvement of service } \\
\text { delivery processes. }\end{array}$ & $\begin{array}{l}\text { Cost reduction for transport } \\
\text { operators. } \\
\text { Improving the service quality } \\
\text { on traffic routes. }\end{array}$ \\
\hline $\begin{array}{l}\text { Use of information } \\
\text { technologies. }\end{array}$ & $\begin{array}{l}\text { Detection of processes, subject to } \\
\text { informatization. } \\
\text { Reorganization of processes using } \\
\text { information technologies. }\end{array}$ & $\begin{array}{l}\text { Reduced operating costs. } \\
\text { Improved route planning and } \\
\text { more effective controls. }\end{array}$ & $\begin{array}{l}\text { Improving management in } \\
\text { transport organizations. } \\
\text { Increasing the quality of } \\
\text { passenger service. } \\
\text { The need for staff training. } \\
\end{array}$ \\
\hline $\begin{array}{l}\text { Increasing revenues of } \\
\text { transport operators. }\end{array}$ & $\begin{array}{l}\text { The most complete use of transport } \\
\text { operators' potential. } \\
\text { Generation of advertising revenue. } \\
\text { Introducing of means of fare } \\
\text { control. }\end{array}$ & Making extra income & $\begin{array}{l}\text { Increased cost-effectiveness of } \\
\text { transport operators. } \\
\text { Formation of positive } \\
\text { cash flows from operating } \\
\text { activities. } \\
\end{array}$ \\
\hline
\end{tabular}


activities; use of information technologies; increase of transport operators' incomes;

2) The specifics and principles of effective strategic planning of urban transport services provision are established. They consist in applying an iterative approach to strategic planning. Its advantages are due to simultaneous execution of any strategic planning work (from writing the following elements of the strategic plan to the fulfilment of its objectives) with continuous analysis of results obtained, which makes it possible to adjust the works according to the changing environment conditions;

3 ) the features of the urban transport services system are revealed, namely: urban public transport systems are complex open dynamic socioeconomic systems. We consider multimodality of external environments, multifactoriality of external influences, presence of internal imbalances in systems as one of the main reasons for their unsatisfactory state. Therefore, a multifaceted approach is needed, which takes into account the maximum number of factors and integrates a set of measures in the field of improving the quality of urban passenger traffic;

4) the main measures for the development of urban public transport services, in particular, for the city of Kyiv, are identified, namely: ensuring multimodal public access to public transport stations and public places; organization of information and communication interaction between all elements of the passenger transportation system; use of various forms of urban public transport fare; mathematical modelling of integration interaction of different types of public transport.

\section{References:}

Adler, Yu. P., Polhovskaya, T. M., Shper, V. L., \& Nesterenko, P. A. (2001). Upravlenie kachestvom. Chast 1: Sem prostyh metodov [Quality control. Part 1: Seven Simple Methods]. Moscow: MISIS. (in Russian)

Akao, Y. (2011). Quality Function Deployment: Integrating Customer Requirements into Product Design. Chicago: American Marketing Association.

Battellino, H. (2009). Transport for the transport disadvantaged: A review of service delivery models in New South Wales. Transport Policy Special Issue International Perspectives on Transport and Social Exclusion, vol. 16:3, pp. 90-96.

Buliung, R., \& Mitra, G. Faulker (2009). Active school transportation in the Greater Toronto Area, Canada: An exploration of trends in space and time (1986-2006). Preventive Medicine, vol. 48, pp. 507-512.

Fedyukin, V. K. (2014). Upravlenie kachestvom processov [Process quality management]. Moscow: Filin. (in Russian)

Fomin, V. N. (2010). Kvalimetriya. Upravlenie kachestvom. Sertifikaciya [Qualimetry. Quality control. Certification]. Moscow: Ekmos. (in Russian)

Fornell, C., Johnson, M. D., Anderson, E. W., Cha, J., \& Bryant, B. E. (2006). The American Customer Satiafaction Index: Nature, Purpose, and Findings. Journal of Marketing, vol. 60 (October 2006), pp. 7-18.

Harshani Dzhon, \& Zelten Rejnhard (2011). Obshaya teoriya vybora ravnovesiya v igrah [General theory of choice of equilibrium in games]. Sankt-Peterburg: Ekonomicheskaya shkola. (in Russian)

Hazanova, L. E. (2008). Matematicheskoe modelirovanie $v$ ekonomike [Mathematical Modeling in Economics]. Moscow: VEK. (in Russian)

Ihnatenko, O. S., \& Ihnatenko, D. O. (2015). Do yakosti transportnykh posluh cherez adaptatsiiu zakonodavstva [To the quality of transport services through the adaptation of legislation]. Avtodorozhnyk Ukrainy [Ukrainian road builder], vol. 12, p. 17.

Markova, V. D. (2006). Marketing uslug [Service marketing]. Moscow: Finansy i statistika. (in Russian)

Taguti, G., \& Fadke, M. (2013). Optimalnoe proektirovanie kak tehnika kachestva [Optimal design as a quality technique]. Metody upravleniya kachestvom [Quality Management Methods], vol. 9, pp. 27-35.

Yanovskyi, P. O. (2018). Pasazhyrski perevezennia [Passenger transportation]. Kyiv: NAU. (in Ukrainian) 